\title{
Migration of Oxidized Cellulose to the Ventricle as a Complication of Endoscopic Third Ventriculostomy: A Case Report
}

\section{Migração da Celulose Oxidada para o ventrículo: Complicação do terceiro ventriculostomia endoscópica (TVE): Relato de caso}

\author{
Aldo J. F. da Silva ${ }^{1}$ Thiago Fortes ${ }^{1}$ Rodrigo C. Bomfim ${ }^{1}$ Ângelo M. S. Bomfim Filho ${ }^{1}$ \\ ${ }^{1}$ Division of Pediatric Neurosurgery, Hospital Geral do Estado, \\ Maceió, AL, Brazil \\ Address for correspondence Aldo J. F. da Silva, MD, R. Barão José \\ Miguel 151, 57055160, Maceió, AL, Brazil \\ (e-mail: neuroajfs@yahoo.com.br).
}

Arq Bras Neurocir 2018;37:349-351.

\begin{abstract}
Endoscopic third ventriculostomy (ETV) is an increasingly common neurosurgical procedure. Hemostatic agentes (porcine gelatin and oxidized cellulose) are normally placed to plug the cortical hole after ETV to avoid cerebral spinal fluid leakage, subdural hygroma, and hemorrhage. Here we report the case of a 6-year-old boy with hydrocephalus who underwent ETV and which oxidized cellulose was placed to plug the cortical hole. Magnetic resonance imaging of the head performed 3 months after the procedure showed the presence of oxidized cellulose in the ventricle. After an unsuccessful attempt to remove the

Keywords

- endoscopy

- cellulose

- leakage

- hydrocephalus

\section{Resumo}

\section{Palavras Chave \\ - endoscopia \\ - celulose \\ - fístula \\ - hidrocefalia} cellulose, it was decided that the patient should be kept under observation. Two years later, the child is in good health and without any complaints. Hemostatic agents (especially oxidized cellulose) used on the cortical hole after ETV can migrate to the ventricle and compromise the procedure. Follow-up should be performed for such patients, and the main focus should be on not causing further injury.

A Terceiro Ventriculostomia Endoscópica (TVE) é atualmente um procedimento neurocirúrgico muito utilizado. Agentes hemostáticos (gelatina suína, celulose oxidada) normalmente são colocados na pequena lobotomia após a TVE para evitar fístula liquórica, higroma subdural e sangramento. Relatamos um caso de uma criança de 6 anos com hidrocefalia que, após realizado a TVE, foi colocada celulose oxidada no local da pequena lobotomia. Depois de 6 meses, ao realizar uma RM de crânio, foi evidenciada a presença de celulose oxidada no ventrículo. Apesar da tentativa de retirada sem sucesso, foi optado por observação e após 4 anos a criança encontra-se bem, sem queixas. A utilização de agentes hemostáticos (principalmente celulose oxidada) na lobotomia após a TVE pode migrar para o ventrículo e comprometer o procedimento. Sempre com a preocupação de não causar mais danos, pode ser feito o acompanhamento do paciente.
\end{abstract}

received

February 17, 2018

accepted

August 31, 2018

published online

October 29, 2018
DOI https://doi.org/

10.1055/s-0038-1675367. ISSN 0103-5355.
Copyright ( $\odot 2018$ by Thieme Revinter

Publicações Ltda, Rio de Janeiro, Brazil
License terms

(c) (1) $\ominus$ (\$) 


\section{Introduction}

Endoscopic third ventriculostomy (ETV) is an increasingly common procedure, especially for the treatment of non-communicating hydrocephalus. ${ }^{1}$ Several studies have confirmed the high success rate and low complication rate of ETV. Therefore, ETV is considered a safe and effective treatment for obstructive or non-communicating hydrocephalus. ${ }^{2,3}$

The literature describes various complications associated with the procedure, including bradycardia, hypothalamic dysfunction, and hemorrhage resulting from artery or ependymal vein lesions or from a choroid plexus lesion. ${ }^{4}$ Hemostatic agents (porcine gelatin and oxidized cellulose) are placed on the cortical hole through which the neuroendoscope is inserted to avoid complications, such as cerebral spinal fluid (CSF) leakage, subdural hygroma, and hemorrhage. ${ }^{1,5}$

In the present article, we report the case of a child with non-communicating hydrocephalus who underwent ETV and subsequently experienced a complication, the migration of the hemostatic agent (oxidized cellulose) to the ventricle.

\section{Case Report}

We report the case of a 6 -year-old boy with classic symptoms of intracranial hypertension (headache, vomiting, and papilledema). Computed tomography (CT) and magnetic resonance imaging (MRI) exams were performed, and the patient was diagnosed with non-communicating hydrocephalus. Subsequently, ETV was performed with no immediate com-

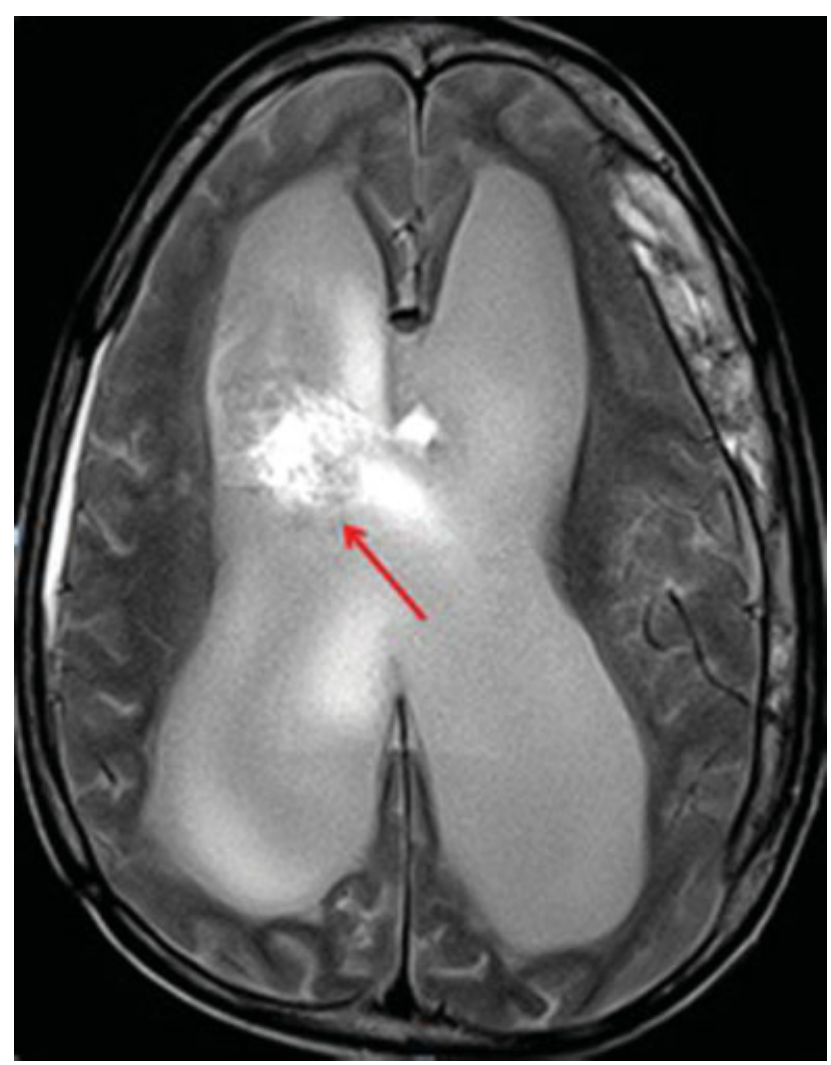

Fig. 1 Axial T2-weighted magnetic resonance imaging showing (arrow) oxidized cellulose in the ventricle.

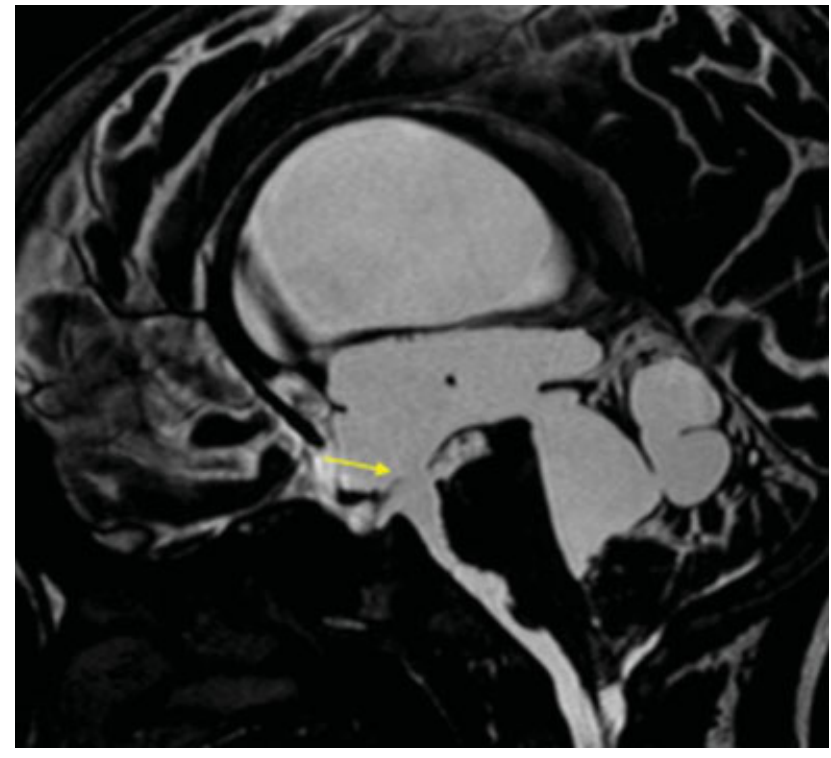

Fig. 2 Sagittal constructive interference in steady state (CISS) image showing (arrow) ventriculostomy patency.

plications. A piece of Surgicel oxidized cellulose (Ethicon, Bridgewater, NJ, USA) was placed on the cortical hole to avoid CSF leakage and achieve local hemostasis. In the immediate postoperative period, the patient recovered well with no complications. On the $5^{\text {th }}$ postoperative day, the patient remained stable and was discharged from the hospital. At the 3-month follow-up, the patient was well and exhibited

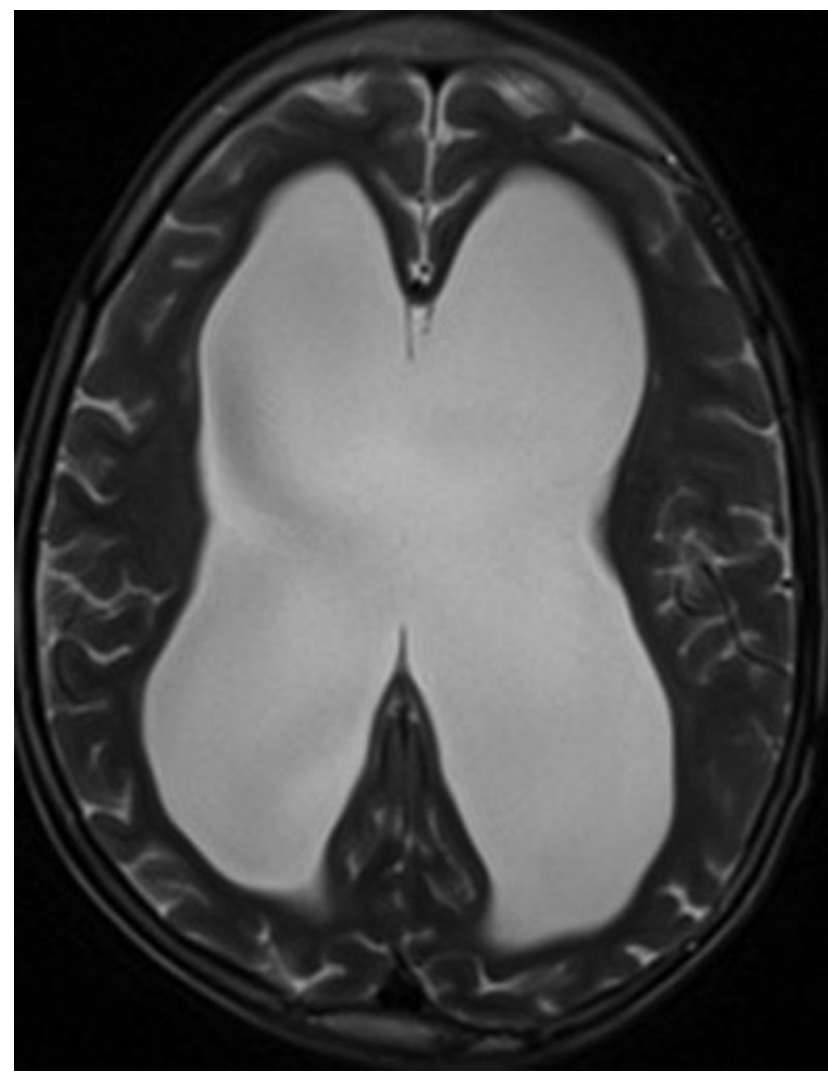

Fig. 3 Axial T2-weighted magnetic resonance imaging. Reabsorption of cellulose oxide. 


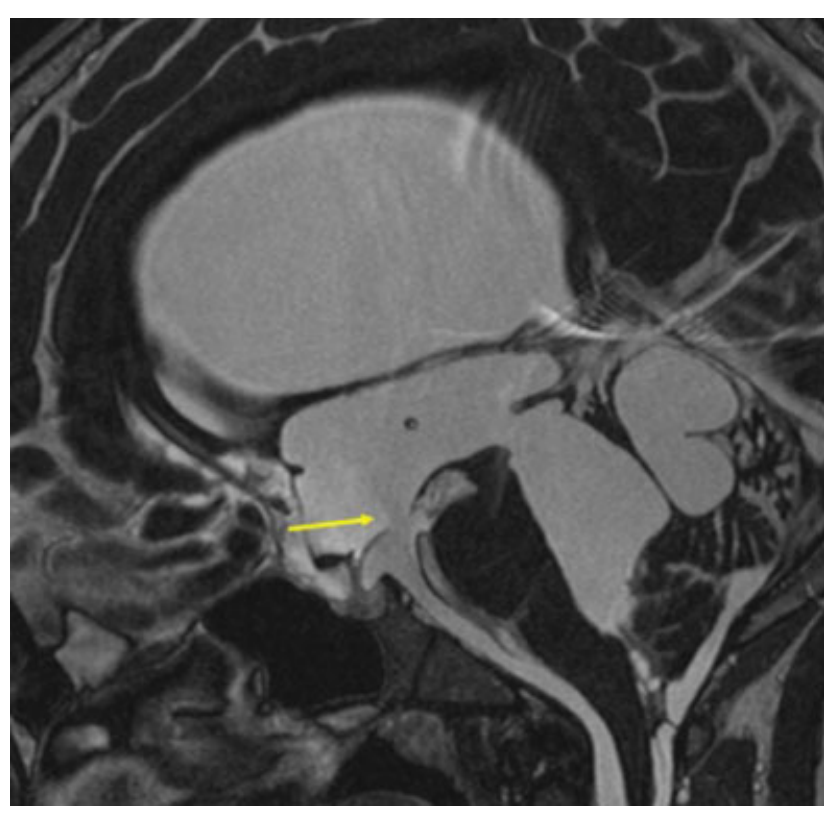

Fig. 4 Sagittal constructive interference in steady state (CISS) image showing (arrow) the flow visible in the region of the floor of the third ventricle.

no neurological complaints. However, an MRI exam to assess the CSF flow was requested to record the performance of the ETV. To our surprise, a piece of oxidized cellulose was found

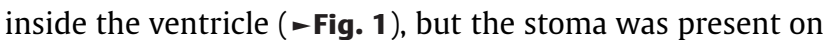
the floor of the third ventricle and CSF flow was observed (-Fig. 2). Another procedure was performed to attempt to remove the oxidized cellulose, but it was not successful because of its adherence to the choroid plexus and the risk of bleeding, which could have caused injury to the patient, who was asymptomatic. Therefore, it was decided that the patient would be monitored with follow-up imaging examinations. After 2 years, the child remains asymptomatic with a functioning ETV (-Fig. 3 and -Fig. 4).

\section{Discussion}

Hemostatic agents (porcine gelatin and oxidized cellulose) are used in several neurosurgical procedures to achieve hemostasis. $^{6-8}$ The hemostatic agent used in the present case was oxidized cellulose, which is a product derived from $\alpha$-cellulose and is available as an absorbable knitted fabric. It acts on the intrinsic pathway of the coagulation cascade and promotes blood clotting. ${ }^{9}$ In this patient, this hemostatic agent was placed on the cortical hole to achieve hemostasis and to avoid complications, such as CSF leakage and subdural hygroma. ${ }^{5}$
When the oxidized cellulose is placed on the cortical hole, a portion of it also covers the tunnel through which the neuroendoscope is inserted. ${ }^{1}$ Thus, oxidized cellulose can migrate to the ventricle, especially if the cortical mantle is thin. There is a risk of this piece of oxidized cellulose migrating and obstructing the stoma made on the floor of the third ventricle. However, depending on the timing of the discovery of the oxidized cellulose within the ventricle, its removal may not be easy and it may be preferable to merely monitor the patient.

\section{Conclusion}

Endoscopic third ventriculostomy is an increasingly common neurosurgical procedure and is therefore associated with several complications until a sufficient degree of experience is attained. The complication reported in the present case was the migration of the hemostatic agent (oxidized cellulose) to the ventricle, which threatened the success of the ETV. However, a close follow-up should be performed in these patients, and a more aggressive intervention may be required.

\section{Conflict of Interests}

The authors have no conflicts of interests to declare.

\section{References}

1 Azevedo Filho HRC, Furtado GJD, Almeida NS, Carneiro Filho GS, Pinho DMB, Cirne de Azevedo RA. Terceiro ventriculostomia endoscópica. Aspectos técnicos-cirúrgicos. J Bras Neurocir 1998;9(02): 45-55

2 Hopf NJ, Grunert P, Fries G, Resch KD, Perneczky A. Endoscopic third ventriculostomy: outcome analysis of 100 consecutive procedures. Neurosurgery 1999;44(04):795-804, discussion 804-806

3 Buxton N, Ho KJ, Macarthur D, Vloeberghs M, Punt J, Robertson I. Neuroendoscopic third ventriculostomy for hydrocephalus in adults: report of a single unit's experience with 63 cases. Surg Neurol 2001;55(02):74-78

4 Teo C, Mobbs R. Neuroendoscopy. In: Rengachary SS, Ellenbogen RG (eds) Principles of Neurosurgery. England: Elsevier; 2005:145-256

5 Teo C. Complications of endoscopic third ventriculostomy. In: Cinalli G, Maixner WJ, Sainte-Rose C (eds) Pediatric Hydrocephalus. Itália: Springer-Verlag; 2004:411-420

6 Schreiber MA, Neveleff DJ. Achieving hemostasis with topical hemostats: making clinically and economically appropriate decisions in the surgical and trauma settings. AORN J 2011;94(05):S1-S20

7 Tomizawa Y. Clinical benefits and risk analysis of topical hemostats: a review. J Artif Organs 2005;8(03):137-142

8 Ereth MH, Schaff M, Ericson EF, Wetjen NM, Nuttall GA, Oliver WC Jr. Comparative safety and efficacy of topical hemostatic agents in a rat neurosurgical model. Neurosurgery 2008;63(04, Suppl 2):369-372, discussion 372

9 Vyas KS, Saha SP. Comparison of hemostatic agents used in vascular surgery. Expert Opin Biol Ther 2013;13(12):1663-1672 